\title{
Treatment of severe actinic rectitis
}

\author{
Surgery Department, Hospital A . C. Camargo e Fundação Antônio Prudente - São Paulo, Brazil
}

\begin{abstract}
Background: The authors report the treatment of three female patients with severe actinic rectitis, with stenosis or perforation, submitted to anterior proctosigmoidectomy and transanal coloanal anastomosis. Methods: In all cases surgery consisted of total proctosigmoidectomy, mucosectomy of the anal canal, lowering of the left colon through the pelvis and transanal anastomosis performed manually at the level of the pectineal line using separate absorbable sutures. A protective intestinal shunt was performed in all cases. Results: The three patients did not present transoperative or immediate postoperative complications, but the first patient developed deep venous thrombosis of the leg that was submitted to successful clinical treatment. The intestinal shunts were later closed in all three cases. Sphincter function was considered very good in the first case and regular in the remaining two. Conclusion: The surgical technique utilized was considered to be adequate for the cases reported and is the first option for the maintenance of transit in patients with severe actinic rectitis since the anastomosis is performed using non-irradiated colon with the pectineal line, practically outside the pelvis.
\end{abstract}

UNITERMS: Actinic rectitis. Coloanal anastomosis. Proctitis. Surgery. Sphincter preservation. Cervix carcinoma.

\section{INTRODUCTION}

$\mathrm{T}$ he sequelae of radiotherapy in the gastrointestinal tract represent a problem of difficult solution even after control of the primary tumor ${ }^{(1)}$. The damage of ionizing radiation is progressive and cumulative and is caused by hyalinization of the arterial vascularization of the affected organ, leading to chronic ischemia with vascular neoformation of the telangiectasia type, which may be an attempt to compensate for the lack of oxygen

\footnotetext{
Address for correspondence:

Benedito Mauro Rossi

Hospital A. C. Camargo - Departamento de Cirurgia

Rua Prof ${ }^{\circ}$ Antonio Prudente, 211

São Paulo/SP - Brazil - CEP 01509-010
}

in tissues. This phenomenon, however, is responsible for the bleeding observed in patients with actinic sequelae ${ }^{(2.3)}$. During the acute phase or the chronic phase, clinical treatment consists of symptomatic relief and palliative measures. Surgical resection of the affected organ is indicated in cases with more severe alterations, such as stenoses, fistulae or intractable bleeding ${ }^{(4)}$.

\section{PATIENTS AND METHODS}

Surgery was indicated for patients with no evidence of active neoplasias, in adequate clinical condition, with good sphincter function and aware of the operative risks, including the possibility of needing a permanent intestinal shunt. 
Surgery consisted of rectosigmoidectomy, including mucosectomy of the anal canal, lowering of the left colon through the pelvis and its manual anastomosis at the level of the pectineal line using separate absorbable sutures. Since this is a high-risk anastomosis, a protective intestinal shunt was performed and closed as soon as the patient was in adequate clinical condition. Anal endoscopy, peranal contrasted radiologic examination and clinical evaluation of sphincter function were performed before shunt closure in order to diagnose possible fistulae or other alterations that might contraindicate the reconstruction of intestinal transit. Patient follow-up by a nurse with specialization in stomotherapy was of fundamental importance.

\section{CASE REPORTS AND RESULTS}

Case 1

A 41 year old woman with spinocellular carcinoma (SCC) of the cervix invading the parametrium up to the pelvic wall (clinical stage IIIb) was treated in 1981 exclusively with radiotherapy. The total dose was 7500 cGy at point A (tumor), with 4000 cGy applied externally to the pelvis using a $4 \mathrm{MeV}$ linear accelerator and 3500 cGy with Fletcher intravaginal applicators. The source was cesium 137. In February 1989 she presented hematuria which was treated clinically, with improvement of signs and symptoms. In March 1990 she presented an increased number of evacuations with cramps, mucus and blood in the feces. Rectosigmoidoscopy showed mucosa which was friable to instrument touch, with edema and vascular neoformation of the telangiectasia type. She was submitted to clinical dietary treatment. In March 1992, symptoms and endoscopic appearance became worse. A biopsy revealed actinic rectitis. In May 1993 she presented acute abdominal pain. Exploratory laparotomy revealed sigmoid necrosis and perforation. Anterior sigmoidectomy was performed, the rectum was closed and a terminal colostomy was carried out. In December 1993 the endoscopic appearance of the rectum was unchanged but the patient had no symptoms. In November 1994 the patient stated that she would not accept her colostomy condition while having no tumoral activity. We proposed surgery and explained its risks to the patient, who accepted the procedure. She was then submitted to anterior resection of the rectum with manual transanal coloanal anastomosis and protective ileostomy. Her immediate postoperative course was free from complications. Anatomopathological examination of the surgical piece revealed chronic rectitis. In December 1994 she developed deep venous thrombosis in a leg which was treated clinically. The ileostomy was closed in February 1995, with no complications.

She currently has good sphincter function and sensitivity to solid or liquid feces and gases, with no nocturnal losses and 1 to 2 evacuations a day. She continues to have actinic cystitis with sporadic dysuria and hematuria, controlled by clinical treatment.

\section{Case 2}

A 71-year old woman with cervical SCC, with invasion of the parametrium up to the pelvic wall (clinical stage IIIb), was submitted to exclusive radiotherapy in October 1978. The total dose was $8500 \mathrm{cGy}$ at point A (tumor), with $4000 \mathrm{cGy}$ applied to the pelvis with a 4 $\mathrm{MeV}$ linear accelerator and $4500 \mathrm{cGy}$ with Fletcher intravaginal applicators. The source was cesium 137. In June 1993 she presented an increased number of daily evacuations, with liquid feces without blood or mucus and was submitted to clinical treatment. In May 1995, a colonoscopy revealed actinic rectitis with thickening of the mucosa, which was pale, with vascular neoformation of the telangiectasia type, easy bleeding upon instrument touch and stenosis of the rectosigmoid transition. In August 1995, in the absence of tumoral activity of the cervical SCC, the patient was submitted to anterior rectosigmoidectomy with manual transanal coloanal anastomosis and protective colostomy. Her postoperative course was free from complications. Anatomopathological examination revealed chronic rectitis with vascular hyalinization and intense fibrosis. The colostomy was closed in December 1995 with no complications. She currently has regular intestinal function with 3 to 4 evacuations a day and feces varying in consistency according to the diet. She presents no diurnal incontinence, with control of gases and feces. At night she has sporadic involuntary losses, especially when the feces are liquid. She sporadically presents urinary symptoms, dysuria or hematuria, which are controlled by clinical treatment.

\section{Case 3}

A 49-year old woman with a cervical SCC with invasion up to the pelvic wall (clinical stage IIIb) was treated in November 1992 by exclusive radiotherapy with 
8000 cGy at point A (tumor), with 4500 cGy applied to the pelvis with a $4 \mathrm{MeV}$ linear accelerator and $3500 \mathrm{cGy}$ applied with Fletcher intravaginal applicators, using cesium 137. In August 1995 she felt abdominal cramps accompanied by vomiting and acute diarrhea. Colonoscopy revealed a rectum with thickened mucosa, obliteration of submucosal vessels, easy bleeding upon instrument touch and stenosis at the level of the rectosigmoid transition preventing passage of the instrument. The intestinal subocclusion improved with clinical treatment. In December 1995 she was submitted to loop sigmoidostomy due to acute intestinal obstruction, with improvement of signs and symptoms. In April 1996, in the absence of tumoral activity of the cervical SCC, she was submitted to anterior rectosigmoidectomy with manual transanal coloanal anastomosis and protective transversotomy. Her postoperative course was good and her colostomy was closed in May 1996 with no complications. She currently has regular intestinal function without incontinence and with sensitivity for feces and gases.

\section{COMMENTS}

Approximately half the patients with malignant neoplasias are submitted to radiotherapy at some time during treatment, and chronic complications may occur in 2 to $5 \%$ of these cases ${ }^{(5)}$. Intestinal changes may occur from 3 to 15 years after radiotherapy. ${ }^{(6)}$.

Some factors have been reported to be predisposing to post-therapy complications, among them previous laparotomy, arterial hypertension, diabetes or emaciation (7). Complications should be mainly prevented by appropriate treatment planning, preferably with the aid of a computer, respecting the maximum dose tolerated by the small intestine ( $4500 \mathrm{cGy})$ and by the rectum ( 5500
cGy) ${ }^{(8)}$. The use of tissue-protecting substances seems to have produced good results in experimental studies ${ }^{(9)}$.

Most pelvic complications after radiotherapy are due to carcinoma of the cervix ${ }^{(1,5,10,11)}$, which is more common in countries where socioeconomic conditions favor the development of this type of tumor. There seems to be no significant correlation with the occurrence of a second primary tumor among patients submitted to pelvic radiotherapy, although a greater incidence of tumors of the rectum and bladder and of leukemia appears to tend to occur among these patients ${ }^{(12)}$.

The major signs and symptoms of the three patients described here are the same as those reported in the literature, i.e., abdominal pain, diarrhea, bleeding and intestinal stenosis ${ }^{(13)}$. The classification of these rectal symptoms may be clinical, such as that proposed by Aeberhard (14) (Table 1), or endoscopic, such as that proposed by Sherman ${ }^{(15)}$ in 1954, in which grades I and II are characterized by edema, easy bleeding and superficial ulcers of the mucosa, and grades II and IV are characterized by important bleeding and deep ulcers that may even lead to the development of fistulae or stenosis. Table 2 shows a clinical-endoscopic classification used in this Department for actinic retitis.

Urinary symptoms such as dysuria and hematuria usually accompany the picture of rectitis, as described for two of the three cases presented here, and can be clinically controlled in a palliative manner since their evolution is also chronic and of difficult treatment, as is the case for the rectum ${ }^{(9)}$. Furthermore, there may be symptoms related to the small intestine such as cramps and abdominal discomfort. In cases in which the terminal ileum is severely involved, surgery may be indicated, such as ileum resection together with the right colon and ileum-transverse colon anastomosis ${ }^{(16)}$. In cases of small intestine obstruction, whenever possible it is better to perform a bypass than a segmental resection with anastomosis, since the former procedure seems to have a lower complication rate ${ }^{(17,18)}$.

\section{Table 1}

\section{Clinical system used to score the morbidity of radiotherapy}

\section{Grade 1}

Grade 2

Grade 3

Grade 4

Grade 5

\author{
Few symptoms requiring no treatment \\ Treatment with no need for hospitalization or a change in patient lifestyle \\ Important symptoms that change patient lifestyle, requiring hospitalization for \\ treatment, including small surgeries \\ Symptoms requiring major surgery (colostomy, laparotomy) or prolonged \\ hospitalization \\ Fatal complication
}




\section{Table 2}

\section{Clinical and endoscopic classification used in the Department of Surgery for actinic rectitis}

$\begin{array}{ll}\text { Grade 1 } & \begin{array}{l}\text { Slight symptoms of easy clinical control } \\ \text { Edema of the rectal mucosa/obliteration of submucosal vessels } \\ \text { Grade } 2\end{array} \\ \text { Mrade } 3 & \begin{array}{l}\text { Easy bleeding upon endoscopic examination/superficial ulcers } \\ \text { Marked symptoms of difficult clinical control }\end{array} \\ \text { Grade } 4 & \begin{array}{l}\text { Diffuse bleeding of rectal mucosa/deep and diffuse ulcers } \\ \text { Clinically uncontrollable symptoms } \\ \text { Fistulae/stenoses }\end{array}\end{array}$

Treatment of severe actinic rectitis symptoms simply by an intestinal shunt may improve the clinical picture, but the tissue process in the irradiated area continues and when the shunt is closed the symptoms come back, at times more exacerbated than before ${ }^{(1,19)}$.

Treatment of rectal bleeding with intraluminal formalin may be indicated, especially in acute and uncontrollable cases, but may also lead to stenosis, without changing the chronic post-irradiation process ${ }^{(20,21)}$. Laser may be used in cases of moderate actinic rectitis in order to control localized bleeding in areas of telangiectasia ${ }^{(5)}$. The use of systemic corticoids may also be indicated in selected cases of actinic rectitis ${ }^{(22)}$.

Proctosigmoidectomy with peranal coloanal anastomosis is definitive in relation to actinic alterations as the lowered colon is not irradiated. The technique was first described by Parks ${ }^{(23)}$ and later used for treatment of cancer of the rectum ${ }^{(24,25,26)}$. It is a technique of difficult execution, especially in terms of pelvic dissection since significant pelvic fibrosis without defined anatomical limits is usually present years after radiotherapy, and besides this, there is an increased post-operative infection rate $^{(1,27)}$. The rates of operative complications may be high, often with the need for the patient to keep a permanent intestinal shunt despite surgery ${ }^{(27,28)}$. In the three patients reported here the complications were not significant but, in view of the small number of cases, this result should be considered with caution.

In conclusion, proctosigmoidectomy including the mucosa of the anal canal and reconstruction of intestinal transit with a peranal coloanal anastomosis is the first treatment option for patients with severe actinic rectitis. The physician should always take into consideration the absence of tumor activity, the clinical condition of the patient and his/her willingness to submit to the surgery proposed after being fully informed about all of its possible complications, including keeping a permanent intestinal shunt, or the presence of such intense pelvic fibrosis that the procedure proposed cannot be carried out.

\section{Resumo}

Proposta: Os autores reportam os resultados do tratamento de três pacientes portadoras de retite actínica severa, com estenose ou perfuração, submetidas a proctossigmoidectomia anterior e anastomose coloanal transanal. Método: A cirurgia realizada para os três casos foi a ressecção de todo o retossigmóide, mucosectomia do canal anal, abaixamento do cólon esquerdo através da pelve e anastomose transanal do mesmo, manualmente, ao nivel da linha pectínea, utilizando fios absorvíveis em pontos separados. Sempre foi realizada uma derivação intestinal de proteção. Resultados: Os três casos nāo apresentaram complicaçōes transcirúrgicas ou no pós-operatório imediato, porém, o primeiro caso desenvolveu trombose venosa profunda de membro inferior que foi tratada clinicamente com sucesso. As derivações intestinais foram fechadas nos três casos. A funçāo esfincteriana foi considerada muito boa no primeiro caso e regular nos dois restantes. Conclusão: A técnica cirúrgica utilizada foi considerada adequada nos casos apresentados, sendo a primeira opção para manutenção do trânsito em pacientes com retite actínica severa, pois a anastomose é realizada utilizando cólon não irradiado com a linha pectínea, praticamente fora da pelve. 


\section{REFERENCES}

1. Cram AE, Pearlman NW, Jochimsen PR. Surgical management of complications of radiation-injured gut. Am J Surg 1977;133:551-3.

2. Marks G, Mohiudden M. The surgical management of the radiation-injured intestine. Surg Clin N Am 1983; 63:81-96.

3. Kinsela TJ, Bloomer WD. Tolerance of the intestine to radiation therapy. Surg Gynecol Obstet 1980;151: 273-84.

4. Lucarotti ME, Mountford RA, Bartolo DCC. Surgical management of intestinal radiation injury. Dis Colon Rectum 1991;34:865-9.

5. Buchi KN, Dixon JA. Argon laser treatment of hemorragic radiation proctitis. Gastrointestinal Endoscopy 1987;33:27-30.

6. Galland RB, Spencer J. Surgical management of radiation enteritis. Surgery 1986;99:133-8.

7. Potish RA, Jones TK, Levitt SH. Factors predisposing to radiation-related small-bowel damage. Radiology 1979; 132:479-82.

8. Mann WJ. Surgical management of radiation enteropathy. Surg Clin N Am 1991;71:977-90.

9. Rowe JK, Zera RT, Madoff RD, et al. Protective effect of RibCys following high-dose irradiation of the rectosigmoid. Dis Colon Rectum 1993;36:681-8.

10. Stryker JA, Bartholomew M, Velkley DE, et al. Bladder and rectal complications following radiotherapy for cervix cancer. Gynecol Oncol 1988;29:1-11.

11. Lillemoe KD, Brigham RA, Harmon JW, Feaster MM, Saunders JR, d'Avis JA. Surgical management of smallbowel radiation enteritis. Arch Surg 1983;118:905-7.

12. Arai T, Nakano T, Fukuhisa K, et al. Second cancer after radiation therapy for cancer of the uterine cervix. Cancer 1991;67: 398-405.

13. Anseline PF, Lavery IC, Fazio VW, Jagelman DG, Weakley FL. Radiation injury of the rectum: evaluation of surgical treatment. Ann Surg 1981;194:716-24.

14. Aeberhard P. Interference between gynecological or urological diseases and proctological lesions. In: MC Marti \& JC Givel (eds.) Surgery of anorectal diseases. SpringerVerlag, Berlin, 1990;.310-7.
15. Sherman LF. A reevaluation of the factitial proctitis problem. Am J Surg 1954;88:773-9.

16. Hoskins WJ, Burke TW, Weiser EB, Heller PB, Grayson J, Park RC. Right hemicolectomy and ileal resection with primary reanastomosis for irradiation injury of the terminal ileum. Gynecol Oncol 1987;26:215-224.

17. Wobes T, Verschueren RCJ, Lubbers EJC, Jansen W, Paping RHL. Surgical aspects of radiation enteritis of the small bowel. Dis Colon Rectum 1984;27:89-92.

18. Smith ST, Seski JC, Copeland LJ, Gershenson DM, Edwards CL, Herson J. Surgical management of irradiation-induced small bowel damage. Obstet Gynecol 1985;65:563-7.

19. Oliveira Fo RS, Fogarolli RC, Rossi BM, Sá AOS, Lopes A. Actinic rectitis - the role of colostomy. Rev Paul Med 1992;110:257-61.

20. Mathai V, Seon-Choen F. Endoluminal formalin therapy for haemorragic radiation proctitis. Br J Surg 1995;82: 190-2.

21. Isenberg GA, Goldstein SD, Resnik AM. Formalin therapy for radiation proctitis (letter). JAMA 1994;272:1822.

22. Goldstein F, Thornton JT. Treatment of chronic radiation enteritis and colitis with salicylazosulfapyridine and systemic corticosteroids. Am J Gastroenterol 1976;65:201-8.

23. Parks AG. Transanal technique in low rectal anastomosis. Proc R Soc Med 1972;65:975-6.

24. Parks AG, Percy JP. Resection and sutured colo-anal anastomosis for rectal carcinoma. Br J Surg 1982;69:301-4.

25. Enker WE, Stearns MW, Janov AJ. Peranal coloanal anastomosis following low anterior resection for restal carcinoma. Dis Colon Rectum 1985;28:576-81.

26. Bernard D, Morgan S, Tassé D, Wassef R. Preliminary results of coloanal anastomosis. Dis Colon Rectum 1989; 32:580-4.

27. Pricolo VE, Shellito PC. Surgery for radiation injury to the large intestine: variables influencing outcome. Dis Colon Rectum 1994;37:675-84.

28. Jao SW, Beart Jr RW, Gunderson LL. Surgical treatment of radiation injuries of the colon and rectum. Am J Surg 1986; 151:272-7. 